\title{
An Analysis of India's trade pattern with BIMSTEC nations- A Gravity Model Approach
}

\section{Sunil Kumar Rai ${ }^{1}$ Anand Shankar Paswan ${ }^{2}$ and Shankar Nath Jha ${ }^{3}$}

\author{
${ }^{1}$ Research Scholar, Faculty of commerce, Banaras Hindu University, Varanasi (U.P.), India \\ ${ }^{2}$ Senior Research Fellow, Faculty of commerce, Banaras Hindu University, Varanasi (U.P.), India \\ ${ }^{3}$ Professor, Faculty of commerce, Banaras Hindu University, Varanasi (U.P.), India
}

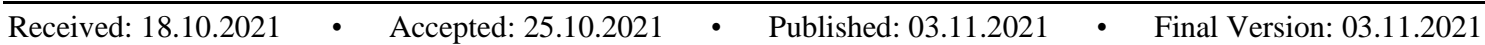

\begin{abstract}
:
Purpose: This paper employs an augmented gravity model to analyze India's trading pattern with Bay of Bengal Initiative for Multi Sectoral Technical and Economic Cooperation (BIMSTEC) nations since its establishment.

\section{Methodology:}

Sampling: The sample countries are all the trading partners of the BIMSTEC nations.

Type of Data: The paper only deals with secondary data collected from various authentic sources such as IMF DOTS, World Development Indicators (WDI), Trade Map, World Trade Organisation (WTO) etc. for the period of 22 years i.e., from 1997-2018.

Econometric Specification: The paper uses the enhanced gravity model proposed by Egger (2002), Serlenga and Shin and Baltagi et al. (2003), to investigate the trading pattern of BIMSTEC (2007). Several tests were carried out to determine whether the panels had serial correlation, heteroscedasticity, or contemporaneous correlation. Many more preliminary tests were run to determine cross-sectional dependency, stationarity, panel co-integration, and variable normality. Regression was carried out using a simple panel OLS estimation method.

Findings: The pattern of trade of India with other nations of the bloc is perfectly explained by Heckscher-Ohlin-Samuelson theorem. The independent variables used in the study, GDP, per capita GDP, Trade GDP ratio, common border and belonging to BIMSTEC, has significantly positive impact on the trade between the India and country j. While tax and distance are negatively correlated with total trade of the nations as per our expectations.
\end{abstract}

Keywords: Gravity model, H-O Samuelson theory, GDP, Economic Growth, Trade, Per capita GDP, Distance, Tax.

\section{Introduction}

The Bay of Bengal is the largest bay in the world, The Bay of Bengal bas been playing prominent role not only confined to bordering countries, in terms of economic development, demographic, security development etc., but also playing pivotal role in shaping Asia as well as global structure. Seven countries are surrounded by the Bay of Bengal which represent one fourth of the entire world's population and around 500 million people live directly on its coastal rim $^{1}$.As being the largest bay, the Bay of Bengal have voluminous unexploited natural resources, seabed mineral, robust reservoir of oil and also enriched with some of the largest reserves of gas in the world ${ }^{2}$. Following that, around onefourth of the world's commercial products pass via the Bay of Bengal every year3, demonstrating the Bay of Bengal's and BIMSTEC's global viability. 
To boost economic growth and make better use of available assets, a regional multilateral organisation known as the Bay of Bengal Initiative for Multi-Sectoral Technical and Economic Cooperation was established in June 1997. (BIMSTEC). Originally called as BIST-EC, this economic bloc was created in 1997 by four member countries: Bangladesh, India, Sri Lanka, and Thailand (Bangladesh, India, Srilanka and Thailand Economic Cooperation). Later that year, on December 22, 1997, Myanmar was admitted, and the team was changed its name BIMST-EC (Bangladesh, India, Myanmar, Sri Lanka, and Thailand Economic Cooperation), and finally in 2004, with the addition of Nepal and Bhutan, the group was changed its name BIMSTEC (Bangladesh, India, Myanmar, Sri Lanka, and Thailand Economic Cooperation) $)^{4}$.

BIMSTEC at present represent 22 percent of the global population and carries immense economic promise, with a combined GDP worth \$ 3.5 trillion (2018) and despite having unfavorable global financial environment BIMSTEC nations were growing at steady rate in the recent past years, all nations were able to grew with a sustain economic growth on an average 5.7 percent annually from 2008 to 2018 , since the global crisis in $2008^{5}$.

The primary objective for the formation of this group is to speed up the economic growth through mutual benefits to each member countries, headway towards combine social progress, promote active collaboration and mutual assistance on common interest and utmost utilization of the untapped resources available and geographical advantages which distinguish them from other regional trading blocs. Unlike other trading blocs the USP of BIMSTEC is that it has been formed as sectoral driven cooperative organization, which includes six priority sectors at rudimentary level viz., trade, tourism, transportation, technology, energy and fisheries.

In the year 2005, in the $8^{\text {th }}$ ministerial meeting held in Dhaka, seven new sectors were included to viz Agriculture, Poverty Alleviation, Public health, Counter- terrorism \& Transportation Crime, Peopleto-People Contact, Environment \& Disaster Management and Cultural Cooperation were the priority sectors $^{6}$. Last sector which get the priority in the BIMSTEC was Climate Change that included in 2008. The weightage to these sectors has been taken in to consideration after cooperation, complementarities among BIMSTEC nations and the untapped resources to be exploit effectively by establishing rail. road, air and shipping networks (Batra, 2010). Another major goal that distinguishes the BIMSTEC team from the remainder of the regional groups is to collaborate on both the 'Look West' and 'Look East' policies, Thailand's 'Look West' policy and the Organization of Southeast Asian Nations' (ASEAN' Look)'s East' policy, and India's and South Asia's 'Look East' policy, as well as to develop a solid connection with ASEAN and the South Asian Association for Regional Cooperation(SAARC). The present scenario of bilateral trade and regional trade is an inevitable part in the world, around 60 percent of the world trade is shelter under the regional trading agreements (RTAs), it is also believed that in the coming years regional economic bloc(s) will play a prominent role in shaping world economy. However, South Asian countries are considered to be the weakest in the world, followed by Sub-Saharan African counties in terms of accomplishing the objectives formed while establishing any regional bloc. The intra-regional trade among the South African Free Trade Area (SAFTA) floats around 4 to 4.5 percent annually (Bhattacharya, 2007). Contradicting this statement BIMSTEC appraise to be more prominent regional trade bloc than the other South Asian regional bloc, table 1 explains the BIMSTEC individual country economic profile since its formation in the year 1997, 2008 and 2018 respectively. Thus, this paper is an attempt to examine the promises and the trade pattern since its formation in June, 1997 to 2018 taking various factors into consideration by using Gravity model. 
Table 1. A comparison between economic indicators of BIMSTEC nations.

\begin{tabular}{|c|c|c|c|c|c|c|c|}
\hline 1997 & Bangladesh & Bhutan & India & $\begin{array}{l}\text { Myanma } \\
\mathbf{r}\end{array}$ & Nepal & $\begin{array}{l}\text { Sri } \\
\text { Lanka }\end{array}$ & $\begin{array}{l}\text { Thailan } \\
\text { d }\end{array}$ \\
\hline $\begin{array}{l}\text { GDP (current US\$, } \\
\text { Billion) }\end{array}$ & 48.24 & 0.37 & 415.87 & 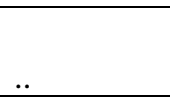 & 4.92 & 15.09 & 150.18 \\
\hline $\begin{array}{l}\text { GDP per capita (US\$ } \\
\text { current) }\end{array}$ & 401.50 & 663.33 & 415.49 & & 217.79 & 817.06 & 2468.18 \\
\hline GDP annual growth $(\%)$ & 4.5 & 5.4 & 4.1 & 5.7 & 5.1 & 6.4 & -2.75 \\
\hline $\begin{array}{l}\text { Agriculture, forestry, and } \\
\text { fishing, value added } \\
\text { (Percentage of GDP) }\end{array}$ & 23.25 & 30.01 & 24.35 & & 38.78 & 21.95 & 9.07 \\
\hline $\begin{array}{l}\text { Manufacturing, value } \\
\text { added (Percentage of } \\
\text { GDP) }\end{array}$ & 14.12 & 9.84 & 16.52 & & 8.85 & 14.81 & 26.71 \\
\hline $\begin{array}{l}\text { Services, value added } \\
\text { (Percentage of GDP) }\end{array}$ & 49.93 & 33.68 & 39.46 & & 33.42 & 51.06 & 54.15 \\
\hline Population (million) & 120.16 & 0.55 & 1000.90 & 45.03 & 22.58 & 18.47 & 60.85 \\
\hline \multicolumn{8}{|l|}{2008} \\
\hline $\begin{array}{l}\text { GDP (current US\$, } \\
\text { Billion) }\end{array}$ & 91.63 & 1.26 & 1198.90 & 31.86 & 12.55 & 40.71 & 291.38 \\
\hline $\begin{array}{l}\text { GDP per capita (current } \\
\text { US\$) }\end{array}$ & 634.99 & $\begin{array}{r}1873.6 \\
0 \\
\end{array}$ & 998.52 & 638.15 & 470.46 & 2037.32 & 4379.66 \\
\hline GDP growth (annual \%) & 6.01 & 4.77 & 3.09 & 10.26 & 6.10 & 5.95 & 1.73 \\
\hline $\begin{array}{l}\text { Agriculture, forestry, and } \\
\text { fishing, value added ( } \% \text { of } \\
\text { GDP) }\end{array}$ & 17.60 & 18.41 & 16.79 & 40.28 & 30.31 & 13.38 & 10.08 \\
\hline $\begin{array}{l}\text { Manufacturing, value } \\
\text { added (Percentage of } \\
\text { GDP) }\end{array}$ & 16.12 & 8.39 & 17.10 & 16.82 & 7.01 & 17.95 & 30.71 \\
\hline $\begin{array}{l}\text { Services, value added } \\
\text { (Percentage of GDP) }\end{array}$ & 52.93 & 35.44 & 45.88 & & 49.20 & 57.25 & 50.34 \\
\hline Population (million) & 144.30 & 0.67 & 1200.67 & 49.93 & 26.67 & 19.98 & 66.53 \\
\hline \multicolumn{8}{|l|}{2018} \\
\hline $\begin{array}{l}\text { GDP (current US\$, } \\
\text { Billion) }\end{array}$ & 274.02 & 2.53 & 2726.32 & 71.21 & 28.81 & 88.90 & 504.99 \\
\hline GDP per capita (US\$) & 1698.26 & $\begin{array}{r}3360.2 \\
7\end{array}$ & 2015.59 & 1325.95 & 1025.80 & 4102.48 & 7273.56 \\
\hline $\begin{array}{l}\text { GDP, annual growth } \\
\text { (percentage) }\end{array}$ & 7.86 & 2.29 & 6.98 & 6.20 & 6.29 & 3.21 & 4.13 \\
\hline $\begin{array}{l}\text { Agriculture, forestry, and } \\
\text { fishing, value added } \\
\text { (Percentage of GDP) }\end{array}$ & 13.07 & 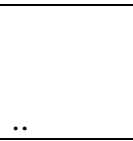 & 14.46 & 24.56 & 24.97 & 7.87 & 8.12 \\
\hline $\begin{array}{l}\text { Manufacturing, value } \\
\text { added (Percentage of } \\
\text { GDP) }\end{array}$ & 17.96 & & 14.99 & & 4.87 & 16.22 & 26.92 \\
\hline $\begin{array}{l}\text { Services, value added } \\
\text { (Percentage of GDP) }\end{array}$ & 52.96 & .. & 49.01 & 43.15 & 50.27 & 56.83 & 56.91 \\
\hline Population (million) & 161.36 & 0.75 & 1352.62 & 53.71 & 28.09 & 21.67 & 69.43 \\
\hline
\end{tabular}

GDP of a nation is considered as one of the key indicators which reflect sustainable growth of a nation, in the same way BIMSTEC members over the last two decades has shown immense potential to grow steadily. In the 1997, BIMSTEC aggregate GDP was recorded worth US\$ 634.67 billion and the 
highest contributor was India with US\$ 415.87 billion, while in 2008, the bloc register more than 2.5 folds growth and the aggregate GDP recorded worth US\$ 1668.29 billion and again the dominating contributor was India with US\$ 1198.90 billion and in 2018, the bloc grew by 2.63 times as compare to 2008, the joint GDP of the BIMSTEC in 2018 was worth US\$ 3690.78 billion and India's share was US\$ 2726.32 billion as the highest in the bloc. India, is the dominating country in the BIMSTEC nations in terms of total share in aggregate GDP of the bloc, India has contributed around (65 percent to 74 percent) in the years 1997, 2008 and 2018 respectively. Another, important economic indicators of any economy are its per capita income, the aggregate GDP per capita income of BIMSTEC in 1997, was US\$ 4983.73 except Myanmar ${ }^{7}$ and the highest contributor was Thailand with GDP per capita of US\$2468.18, where as in 2008, the aggregate GDP per capita of the bloc worth US\$ 11032.7 and again the highest contributor was Thailand with US\$ 4.379.66, while in 2018, the bloc grew almost 2 times as compare to 2008 , the aggregate GDP per capita was recorded worth US\$20801.91 and highest share was again by Thailand US\$ 7273.56.

\section{Review of Literature}

The Reviewed literature can be divided into two streams

1. Firstly, investigation of on the basis of bilateral or regional trade blocs.

2. Secondly, by the application of gravity model to explore the existing trade pattern among the blocs.

Choudhury et al. (2018) discussed about the various challenges of BIMSTEC regarding the composition, potential, priorities and recent developments and the suggestions to overcome them in their article 'BIMSTEC: Relevance and Challenges'. The authors discussed that the BIMSTEC is growing and operating at a slow pace as the co-operation between the nations is less than satisfactory particularly on FTA. However, the outcomes of $4^{\text {th }}$ summit are positive and many important steps have been taken after that, such as, development of infrastructure for transport connectivity. The authors discussed that BIMSTEC is getting side lined because of the other upcoming connectivity projects, like the Free and Open Indo-Pacific and Belt and Road Initiative.

Kumar Mishra et al. (2015) examined the trade patterns of India patterns with the BRICS nations by employing a gravity model on the data which accounts for the period from 1990 to 2010. Using the panel OLS approach to determine, the research discovered the significant positive relationship between a country's GNP/Per Capita GNP and trade intensity, as well as a negative relationship between BRICS countries' transport costs and exchange rates, import-GDP ratio, and inflation rate that had no impact on trade density.

Farkhondeh Jabalameli et al. (2018) examined the BRICS trade patterns with five United Nations regionals groups by applying panel gravity model during 2001-2015. The findings reveal that the BRICS economies trade differently, particularly Russia, due to its unique trade framework and foreign trade practices. Furthermore, Russia's trade model is predicated on the Heckscher-Ohlin hypothesis, whereas the rest of the BRICS countries follow the Linder assumption.

Amita Batra (2013) used an augmented gravity model to evaluate practically all international commerce in the year 2000 in order to determine India's trading possibilities with the rest of the world. Cross sectional data for the year 2000 was analyzed using OLS estimate methods. Further, the macroeconomic scale of the two countries, as well as their geographical proximity, historical and cultural similarities, have been demonstrated to have a positive impact on bilateral commerce.

$\mathrm{Xu}$ Wang et al. (2016) investigated Peru's foreign trade by using multifaceted panel gravity model, try to find out Peru's export role in shaping economic growth, with assistant of the augmented trade gravity model by estimating fixed effect, random effect and GMM regression. Empirical finding 
suggests that Peru's GDP, importers GDP, Peru's per capita income, distance reduction had a significant effect in Peru's export.

Masudur Rahman et al. (2016) examined the economic integration of BIMSTEC members taking investment and trade scenario, the study found that BIMSTEC members completely abolished import tariffs with each other and India, Thailand and Bangladesh are expected to gain more benefits from the abolishment of import tariffs.

Bihn et al. conduct research on trade activities of Vietnam with 60 countries by employing gravity model in the study and concluded that the economic size, market size, distance and culture of the Vietnam and other nations have huge effect on the trade flows between them. The study also reveals that the Vietnam has greater trade potential with the new markets such as Africa and Western Asia.

Bhattacharya Ranajoy et al. (2006) investigated if the gravity model can describe India's trade orientation with all of its trade agreements, and found that it can only explain roughly 43-50 percent of the variance in India's trade orientation. It also shows that India trades more with developed countries than with developing countries.

Laskar, Sabina et al. (2014) used the gravity model to find out the determinants of Trade and FDI flows in BRICS nations by employing the GDP of the nations with lagged values, distance between the nations, common border, common language, and the countries population as independent variables using gravity model. Their studies concludes that the bilateral trade and the FDI flows of the countries are positively correlated with the market size of the nations, and negatively correlated with distance between them. However, the common language and the GDP growth rate are insignificant to the FDI flows and bilateral trade between the nations.

Garcia (2012) used dynamic panel data and the Blundell and Bond test to examine the impact of economic markets on financial development in transition nations (1998). Economic liberalization has a large and favourable association with the growth of the financial system, but it is not the only variable that determines the design process, and it does not improve the performance of basic financial activities.

Kabir mahfuz et. al. It use a gravity model of trade to investigate BIMSTEC's trading pattern. The results suggest that BIMSTEC importing reflect the Linder hypothesis, whereas exports exhibits the Heckscher-Ohlin-Samuelson prototype. Their results also exhibits that the distance between the nations are significant and negatively correlated. Common language, bilateral trade agreement and governance of all the BIMSTEC nations have positive effect on both import and export while the real depreciation is only export enhancing.

Bhattacharya swapan, k. et al.tried to find out which country whether India and China gains or losses in their bilateral trade by applying gravity model of trade. The result reveals that the free trade agreement favors China in short-run while it is unfavorable for India in short run because of high tariff regime in India. In long run, India gains higher than China, once its tariff levels are brought down at par with China.

Kandil et al. (2015) used panel co-integration and panel Vector autoregression to examine the influence of globalization on economic literacy in a panel of 32 developed and developing nations over the period 1989-2012. (VAR). The findings suggest that financial advancement has a positive impact on economic growth and globalization, and that there is a bidirectional relationship between globalization and economic growth. However, globalization does not aid financial development but rather improves access to external capital.

Rani and Kumar (2018) conducted a study on export or import led growth in BRICS nations using Pedroni's panel co-integration test, FMOLS, dynamic OLS and vector error correction model and discovered the existence of long-run relationship between the exports, imports, and GDP growth between the BRICS countries. The study also reveals that there exist an Export led growth between the BRICS nations. 
3. Objective: The sole objective of this paper is to analyses the trading pattern of India with BIMSTEC member nations using augmented gravity model of trade and several tests.

\section{Methodology}

4.1 Sampling: The sample countries are drawn from all BIMSTEC member nations, including Bangladesh, India, Sri Lanka, and Thailand, which are the trade bloc's founders. The main choice reveals that nations that entered the bloc later after its enlargement had a higher impact on current bilateral trade figures and are more significant than data from the distant past. As a result, all of the member nations were used as a sample for this study.

\subsection{Data:}

4.2.1 Nature: The data used to conduct the analysis is purely of secondary nature and is in the panel form.

4.2.2 Period: The data has been collected for the period of 1997-2018, i.e., for 22 years, to measure the India's trade pattern among the bloc.

4.2.3 Sources: Data has been collected for all the 7 BIMSTEC member nations through various sources. The annual data on total exports and imports are aquired from $\mathrm{IMF}^{1}$. Data on GDP, per capita GDP and trade tax are gathered from World Development Indicators (WDI) ${ }^{2}$ and are calculated in US dollars. The statistics on distance and common border are collected from the database of Centre of Etudes Prospectives and Information Internationales (CEPII) ${ }^{3}$. The data on membership of the nations have been derived from BIMSTEC official website ${ }^{4}$.

\footnotetext{
${ }^{1}$ https://data.imf.org/

2 https://databank.worldbank.org

3 http://www.cepii.fr/CEPII/en/

4 http://bimstec.org/
}

\section{The Model:}

"The gravity model is based on Newton's gravitational physics hypothesis. According to Newton's widespread law of gravitation, everybody in the world tends to attract every other body with a force (constant of gravitation) that is directly proportional to the product of each body's mass and inversely proportional to the square of the range between their gravitational centers".

$F=G \frac{m_{1} m_{2}}{r^{2}}$

Where, $\mathrm{F}$ is the gravitational force between the bodies; $\mathrm{G}$ is the gravitational constant; $\mathrm{m}_{1}, \mathrm{~m}_{2}$ are the masses of bodies and $r$ is the distance between the centers of the bodies.

A Dutch economist, Jan Tinbergen (1962), discovered symmetry with Newton's universal law of gravitation to explain the bilateral trade flow pattern between 2 nations. According to his approach, trade flows between 2 nations are directly related to their GDP and inversely proportional to the distance between them. In its most basic version, the Gravity model equation (for trading) is as follows: $T_{i j}=A \frac{G D P_{i} * G D P_{j}}{D^{2}{ }_{i j}}$

Where, $T_{i j}$ is the aggregate value of trade flow between countries $i$ and $j$; A is used as constant, $G D P_{i(}$ ${ }_{j}$ ) is the gross domestic product of both the countries $i$ and $j$ and $D_{i(j)}$ is the distance between two countries.

Since then, many economists, including Poyhonen (1963), Martinez-Zarzoso and Nowak-Lehmann (2004) et al., and other researchers, have used the gravity model of trade to study and examine the pattern of bilateral trade between countries, and it has demonstrated remarkably steady and precise over time across diverse samples of countries and methods. 
According to the generalised gravity equation of trade, the accumulated amount of trade/import/export between two countries, Xij, is determined by their incomes (GDP/GNP), distance between them (a proxy for the cost of transportation), their populations, and a number of dummy variables that either restrict or facilitate trade between countries. Per capita income is a good proxy for a country's population as well as a measure of infrastructure development and economic growth, all of which are important for conducting commerce. The more developed a country is, the more trade it will undertake between countries (Frankel, 1993). It can be written as the following equation:

$X_{i j}=\beta_{0} \beta_{1} Y_{i} \beta_{2} Y_{j} \beta_{3} N_{i} \beta_{4} N_{j} \beta_{5} D_{i j} \beta_{6} A_{i j} U_{i j}$

Where,

$Y=$ GDP of the country $i, j$,

$N=$ population of the country $i, j$,

$D i j=$ the distance between the capitals of two countries,

$A i j=$ dummy variables,

$U i j$ is the error term and $\beta$ 's are parameters of the model.

Gravity model can also be linearized by taking the natural logarithm of all the variables. So, the model can also be expressed in log-linear form in year $t$ as :

$\ln X_{i j t}=\beta_{0}+\beta_{1} \ln Y_{i t}+\beta_{2} \ln Y_{j t}+\beta_{3} \ln y_{i t}+\beta_{4} \ln y_{j t}+\beta_{5} \ln D_{i j t}+\beta_{6} A_{i j t}+U_{i j t}$

where $y$ is per capita income of the country $\mathrm{i}$ and $\mathrm{j}$ in the year $\mathrm{t}$.

Based on econometric definition of Baltagi et al.(2003), Egger(2000,2002) and Serlenga and Shin(2007), the paper states the following augmented gravity model of trade to estimate and analyse the bilateral trading pattern of India with BIMSTEC nations :

$\ln \left(\mathrm{X}_{\mathrm{ijt}}\right)=\alpha_{0+} \alpha_{1} \ln \left(\mathrm{GDP}_{\mathrm{it}}+\mathrm{GDP}_{\mathrm{jt}}\right)+\alpha_{2} \ln \left(\mathrm{PCGDP}_{\mathrm{it}}+\mathrm{PCGDP}_{\mathrm{jt}}\right)+\alpha_{3} \ln \left(\mathrm{TAX}_{\mathrm{it}}+\mathrm{TAX}_{\mathrm{jt}}\right)+$

$\alpha_{4} \ln \left(\right.$ Distance $\left._{\mathrm{ij}}\right)+\alpha_{5} \ln \left(\mathrm{PCGDPD}_{\mathrm{ijt}}\right)+\alpha_{6} \ln \left(\frac{T R}{G D P_{i t}}\right)+\alpha_{7} \ln \left(\frac{T R}{G D P_{j t}}\right)+\alpha_{8}\left(\right.$ Border $_{+}+\alpha_{9}\left(\right.$ Bimstec $\left._{\mathrm{ijt}}\right)+\mathrm{U}_{\mathrm{ijt}}$

where,

$X_{i j}=$ total trade between India (country $i$ ) and country $j$,

$G D P_{i}\left(G D P_{j}\right)=$ gross domestic product of country $i(j)$,

$P C G D P_{i}\left(P C G D P_{j}\right)=$ per capita GDP of country $i(j)$,

$\operatorname{Tax}_{i}\left(\operatorname{Tax}_{j}\right)=$ trade tax as $\%$ of revenue of country $i(j)$,

Distance $_{i j}=$ distance between country $i$ and country $j$,

$P C G D P D_{i j}=$ per capita GDP differential between country $i$ and $j$,

$T R / G D P_{i(j)}=$ trade-GDP ratio of country $i(j)$,

Border $_{i j}=$ common land border between country $i$ and $j$ (dummy variable),

Bimstec $=$ Dummy variable (takes 1 if country $i / j$ is member of BIMSTEC, otherwise 0$)$

$U_{i j}=$ error term,

$t=$ time period,

$\alpha$ 's $=$ parameters.

\subsection{Explanation and Reasons of Explanatory Variables}

Total Trade: Annual trade (imports plus exports) between India and partner countries is the dependent variable. This variable's data collected from the World Bank database. Total trade will define the trade relations and trading pattern of India with other BIMSTEC member nations.

GDP: The Gross Domestic Product (GDP) of India and other members of the bloc is used to assess their economic growth and size. The broader the diversity of products available for commerce, the higher a country's GDP. The larger the bilateral trade volume between nations, the more similar they are in terms of GDP. Thus, with economies of scale and a variety of items, the amount of trade depends, in a key sense, on a country's GDP/GNP size (Paas, 2000). For our projected model, we assumed constant GDP (in billions of dollars). 
Per Capita GDP: Per capita GDP is used as an independent variable since it reflects the level of development. This variable is often used to analyses bilateral trade flows since the gravity model suggests that nations with similar rates of per capita production should trade more than the others. The per capita GDP definition, in particular, helps to examine the relationship between a country's trade and its stage of development. As a country develops, the desire of consumers for more luxurious foreign goods gets increased, which are of superior nature (Bergstand, 1990, Frankel,1997). Further, the development process may be led by the invention or innovation of various goods and services which are then demanded by other countries (Breuss and Eggar, 1999). Since, the more developed countries have more new and advanced transport infrastructures to facilitate and promote trade.

Trade volumes are also expected to rise with an increasingly equivalent distribution of GDP (HelpmanKrugman theory). This concept predicts that per capita GDP will favorably effect trade. Constant per capita GDP ( $\$ 1$ billion) has been used for our projected model.

Per capita GDP differential: The Heckscher-Ohlin assumption or the Linder theory of trade has been tested using the per capita GDP differential. The existence of either assumption will be demonstrated by the frequency of this variable. According to the 'Heckscher-Ohlin' theory, countries with different levels of per capita income will trade more than those with equal levels. The Linder (1961) assumption, on the other hand, argues that countries with similar levels of per capita income should trade more among themselves since they will have similar preferences for different items. As a result, the Heckscher-Ohlin hypothesis is associated with a positive influence of the difference in per capita GDP between countries I and $\mathrm{j}$ on bilateral trade and will yield a favourable result (Baskaran et. Al., 2011). The Linder theory is linked to a negative influence of this feature.

TAX: This variable has been used as the proxy for trade policy between the countries $i, j$. The more liberal the policy the greater trade would be between the countries, i.e., lesser the tax for the trade imposed the more the trade would be between them. Thus, the negative sign is expected for this variable in bilateral trade.

Trade-GDP ratio: This variable has been used as the proxy for trade openness of the nation. The more open the nations would have the higher trade between them. Thus, the expected sign for this attribute is positive.

Distance: In trade, the cost of transportation is a critical consideration. Due to transportation costs and variations in need among nations, separate trade model may behave differently (Paas, 2000, Davis and Weinstein, 1996). The range is used to estimate transportation expenses. As a result, the commerce volume between nations is inherently determined by their distance. The distance between the capitals of countries I and $\mathrm{j}$ has been calculated (Byers, 1997). As the distance between points grows, so do the expenses of shipping. As a result, this variable's anticipated sign is negative.

The following three dummy variables were also incorporated to see how geographical and historical relationships between nations involved in bilateral trade influenced the results. These are described in more detail below.

Border: A shared border leads to lower transportation costs and easier market access, both of which benefit trade flows. Countries with shared borders are more inclined to trade than nations with separate borders. Countries that share a shared border with India receive a value of 1; otherwise, they receive a value of 0 .

BIMSTEC: If a country is member of BIMSTEC must be having a bilateral trade agreement with the other member nations trade which leads to lower cost of trade due to minimised trade barriers and thus trade increases (Frankel and Rose, 2002, Papazoglou et al., 2006). If the country is member of BIMSTEC in the year $\mathrm{t}$, takes 1,0 otherwise. 
Table 2. Variables with expected sign to be observed in test.

\begin{tabular}{llll}
\hline Variables & Symbol & Type & Expected Sign \\
\hline GDP & LGDP & Time-variant & + \\
Per capita GDP & LPGDP & Time-variant & + \\
Per capita GDP difference & LPCGDPD & Time-variant & + \\
& & & \\
Trade tax & LTAX & Time-variant & - \\
Trade GDP ratio & LTRGDP & Time-variant & + \\
Distance & LD & Time-invariant & - \\
Border & BOR & Time-invariant & + \\
Bimstec member & BIMSTEC & Time-invariant & + \\
\hline
\end{tabular}

\section{Preliminary and Emperical tests:}

\subsection{Cross Sectional Dependence:}

"According to Hsiao, Hashem Pesaran, and Rich (2011) and Xu, Cai, and Fang (2012), panel sets of data are most likely to display significant cross-sectional dependency (2016). The Breusch-Pagan Lagrange multiplier (LM), Pesaran-Scaled LM, and Pesaran Cross-Sectional Dependence tests are all useful for panel data (CD)".

Breusch-Pagan Lagrange Multiplier (LM):

Breusch - Pagan $L M=\sum_{i=1}^{N-1} \quad \sum_{j=i+1}^{N} T_{i j} \hat{P}_{i j}^{2} \rightarrow \mathrm{X}^{2} \mathrm{~N}(\mathrm{~N}-1) / 2$

In which the $\hat{p}_{i j}$ indicates the correlation coefficients from the residuals of the model.

Pesaran Scaled Lagrange Multiplier :

Pesaran Scaled LM $=\sqrt{\frac{1}{N(N-1)}} \sum_{i=j}^{N-1} \sum_{j=i+1}^{N}\left(T_{i j} \hat{P}_{i j}^{2}\right) \rightarrow_{\mathrm{N}(0,1)}$

Pesaran CD:

Pesaran CD $=\sqrt{\frac{2}{N(N-1)}} \sum_{i=j}^{N-1} \sum_{j=i+1}^{N}\left(T_{i j} \hat{P}_{i j}^{2}\right) \rightarrow_{\mathrm{N}(0,1)}$

As a result of these tests, the null hypothesis (no cross-sectional dependence in residuals) can be strongly rejected. It exhibits that all of our series have strong proof for cross sectional dependence.

Table 3. Cross Section Dependence Test

\begin{tabular}{lccc}
\hline Test & Statistic & d.f. & Prob. \\
\hline Breusch-Pagan LM & 65.90178 & 15 & 0.0000 \\
Pesaran scaled LM & 9.293351 & & 0.0000 \\
Pesaran CD & 1.830663 & & 0.0672 \\
& & & \\
\hline
\end{tabular}

* Author's compilation from eviews 10 .

\subsection{Unit Root test:}

Before going any further, we checked the data for stationarity. Despite the fact that the series has showed some changes over the years, it always looks to wander erratically. As a result, unit root tests must be performed to check whether the series are stationary from 1997 to 2018. The Im, Pesaran Shin(IPS), the ADF-Fisher Chi-Square, and the PP-Fisher Chi-Square are three typical panel unit root 
tests that we employed. The ADF regression of each cross-section was established by these three panel unit roor tests (Al-mulali and Che Sab,2012).

$$
\Delta y i t=\alpha_{y i t-1} \sum_{j=1}^{p_{i}} \beta i j \Delta y i t-j+X i t \delta+\varepsilon i t
$$

Where the null hypothesis is $\mathrm{H}_{0}: \alpha=0$, for all $\mathrm{i}$. The result of the unit root tests exhibit that the series are not stationary at levels, while they are stationary at the first difference, rejecting the null hypothesis and showing that the series contains a panel unit root (Appendix 1)

\subsection{Panel co-integration test:}

"Pedroni's panel cointegration test was used to examine if the variables had any cointegrated correlations $(1999,2004)$. The test contains two kinds of data. The first are the within-dimension methods of panel v-statistic, panel p-statistic, panel PP-statistic, and panel ADF-statistic. These data include unit root tests on the calculated residuals and aggregated autoregressive coefficients across all BIMSTEC members, taking into consideration heterogeneity and temporal variables within the BIMSTEC nations. The second set of stats is the unit average panel co-integration statistics, which are based on the between-dimension approach and consist of three statistics: group p-statistic, group ppstatistic, and group ADF-statistic. Apergis and Payne, (2009) argued that there is an asymptotic probability for each of these seven statistics. Table 4 reveals that when contrasted to the other explanation of co-integration, five of the seven panel co-integration tests reject the null hypothesis of no co-integration (Pedroni, 2001a, 2001b)".

Table 4. Panel Co-integration Test

Null Hypothesis: No cointegration

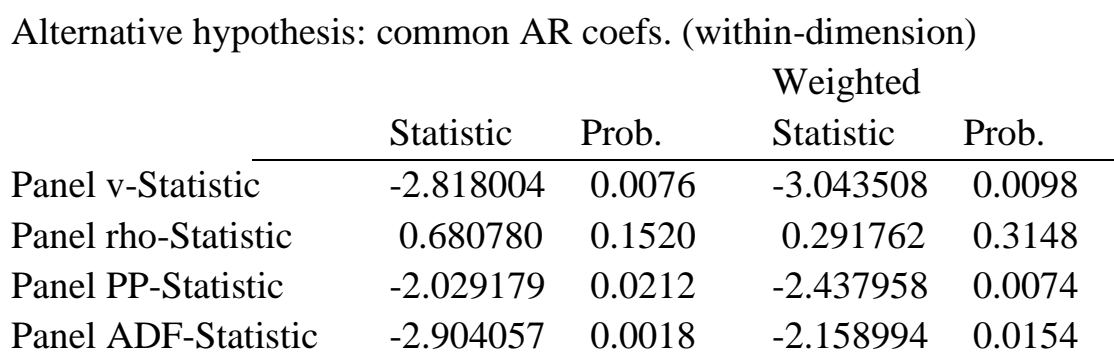

Alternative hypothesis: individual AR coefs. (between-dimension)

\begin{tabular}{lcc} 
& Statistic & Prob. \\
\cline { 2 - 3 } Group rho-Statistic & 2.747655 & 0.0470 \\
Group PP-Statistic & 0.025063 & 0.2100 \\
Group ADF-Statistic & -1.049078 & 0.1471 \\
\hline
\end{tabular}

*Author's compilation from eviews 10.

\subsection{Panel OLS Estimation Result:}

Because there are few variables that do not change greatly over time, we end up with a singular matrix, making the Fixed Effect Method (FEM) model impractical to utilise. As a result, we used the Panel Ordinary Least Square (OLS) model. Table 5 shows the augmented gravity model's ordinary least square (OLS) estimates.

We've used total trade between India and country (j) as the dependent variable, with GDP, per capita GDP, per capita GDP differential, tax, trade to GDP ratio as a measure of economy openness, distances 
between capitals of countries I and $\mathrm{j}$, and Bimstec as a proxy for Bilateral Trade Agreement and Common Border as the independent variables.

Except for the per capita difference, tax, and BIM, all of the variables appear to be significant in the table. The assumption is that the Heckscher-Ohlin model, not the Linder assumption, can explain the structure of India's trade with BIMSTEC nations, therefore the positive sign of per capita GDP differential. A positive value of 0.014 is obtained. According to the Heckscher-Ohlin model, two countries with complementary trade structures are more likely to grow bilateral volume of trade through inter-industry trade. The model indicates that BIMSTEC's commerce will increase.

Table 5. Panel OLS estimation

\begin{tabular}{lllll}
\hline Variable & Coefficient & Std. Error & t-Statistic & Prob. \\
\hline LGDP & 1.008854 & 0.004928 & 204.7192 & 0.0000 \\
LPCGDP & 0.029856 & 0.008811 & 3.388495 & 0.0010 \\
LPCGDPD & 0.014327 & 0.007428 & 1.928836 & 0.0565 \\
LTAX & -0.011902 & 0.014057 & -0.846681 & 0.3991 \\
LTRGDPIT & 0.694645 & 0.002436 & 408.2712 & 0.0000 \\
LTRGDPJT & 0.031799 & 0.005604 & 5.674170 & 0.0000 \\
LDISTANCE & -0.025585 & 0.010057 & -2.544109 & 0.0124 \\
BIM & 0.004904 & 0.004396 & 1.115490 & 0.2672 \\
BORDER & 0.052283 & 0.007019 & 7.448454 & 0.0000 \\
& & & & \\
\hline R-squared & 0.999720 & Mean dependent var & 3.115481 \\
Adjusted R-squared & 0.999698 & S.D. dependent var & 0.625195 \\
S.E. of regression & 0.010862 & Akaike info criterion & -6.130734 \\
Sum squared resid & 0.012271 & Schwarz criterion & -5.913508 \\
Log likelihood & 355.3865 & Hannan-Quinn criter. & -6.042586 \\
Durbin-Watson stat & 2.313326 & &
\end{tabular}

*Author's compilation from eviews 10

Instead of economies of scale or product diversification, competitive advantage, income disparity, and the degree of growth stage gap impact flows. In the gravity model, the H-O theory specifies a limited degree of vertical intra-industry trading, according to Kandogan (2003). As evidenced by the positive sign of per capita GDP differential (LPCGDP) in the panel, BIMSTEC follows an H-O trading pattern with inter-industry dominating and modest vertical intra-industry exports.

"Overall trade has a negative link with both nation-to-nation distance and tax, but a positive relationship with GDP, per capita GDP, trade-GDP ratio, BIM, and border. Serlenga and Shin (2007) found Total GDP and PCGDPD to be positive and significant using standard Ordinary Least Square, Fixed Effect Estimation (FEE), Random Effect Estimation (REE), and Hausma-Taylor Prediction. As according our findings, the distance between two countries has a negative impact on bilateral trade. In our research, we discovered a regression association that reflects the same; nevertheless, the coefficient of determination is 0.02 , indicating that a 100 percent drop in distance between merchants results in a $20 \%$ rise in trade volume. The distance coefficient has less significance than the other elements in the panel. This could be because it was used as a proxy variable for transportation costs in our study, but it's also possible that other factors, such as the country's policies, are impacting it. The R-square value of the model is 0.99 , indicating that it is significant and that the modelled and observed values are consistent".

\section{Empirical Results of the Model:}


For seven BIMSTEC countries, Bangladesh, Bhutan, India, Myanmar, Sri Lanka, Thailand, and Nepal, we utilized data from 1997 to 2018 . Because some of the data is missing, a few occurrences of the variable foreign trade tax have been linearly interpolated to provide a balanced and correct panel data set. Because a fixed effects model could not be used attributed to the prevalence of certain time invariant variables, we used the conventional panel Ordinary Least Square estimation technique.

The size of the business is measured by the sum of GDPs. The higher it is, the more bilateral trade between two countries will be; in our model, we see a positive association between total trade and economic size, which supports the idea. Per capita GDP is a good proxy for the infrastructure expansion and degree of development needed to conduct commerce, and the more developed the countries are, the more bilateral trade there will be between them (Frankel, 1993). Because we get a coefficient of around.02 for per capita GDP in our estimation model, this shows that has a large positive impact on trade between the two countries, corroborating the previous conclusion.

Trade taxes are frequently used as a trade barrier. Transport expenses are also inversely proportional to commerce flow. In our investigation, we discovered that its coefficient is approximately 0.01 , indicating the previously mentioned negative association. According to our findings, the distance between two countries is likely to have a detrimental impact on any country's commerce. A negative coefficient of -0.02 is obtained, implying the same. The $\mathrm{H}-\mathrm{O}$ theory predicts that countries with similar per capita income will trade more than the other two. A positive value of 0.01 implies that overall trade between two countries is influenced by each country's per capita income. The TR/GDP metric represents the country's trade openness. The more accessible a nation is, the more trade it will generate. We also discovered that it is essentially minor in the case of BIMSTEC countries, although it has a positive sign, corroborating the point provided.

The positive value of the variable BIM suggests that membership in BIMSTEC has a positive impact on trade flows between nations, but the coefficient of 0.004 indicates that it has only a minor impact on trade flows, which is consistent with the findings of Egger (2002) and Baltagi et al (2003). The positive sign of variable BORDER, which has a value of.05, suggests that countries sharing a shared border trade more than countries that do not.

The model's R-square score of 0.99 shows that the model fits the dependent variable's estimated and observed values well (i.e., total trade). The fact that the modified R-squared value is significant also excludes the possibility of kitchen sink regression.

\section{Conclusions}

It has been widely recognized that increased commerce resulting from enhanced economic cooperation may support regional and global economic growth (Yoonus and Banik, 2012), and the BIMSTEC countries have made major contributions in this regard. In this study, a gravity model model was used to evaluate the parameters impacting India's bilateral trade with BIMSTEC nations and to evaluate the trade connection between India and other BIMSTEC countries. The regression analysis produces fascinating results that are mainly consistent with gravity predicted values for other economic blocs. Panel OLS regression analysis, which allows for heteroscedasticity, panel-specific serial correlation, and cross-sectional reliance, was used due to the presence of heteroscedasticity, cross-sectional dependence, and serial correlation.

The findings are noteworthy and expressive in terms of understanding India's trade pattern with BIMSTEC countries, and they back up the theoretical model. The GDP of trading partners has a favourable impact on bilateral trade. The overall trade and GDP, per capita GDP, per capita GDP differential, and trade-GDP ratio all show a positive association. In the specifications, distance elasticity and tax are both negative. The study also found that trade flows are generally and negatively linked with distance/transport cost and tax, with coefficients of around 0.025 and -0.01 , respectively. The effect of the per capita GDP disparity was likewise found to be consistent with expectations. Furthermore, the Heckscher Ohlin-Samuelson theorem explains the pattern of trade between India and 
the other members of the bloc, concluding that countries with similar GDP/per capita GDP have higher bilateral trade. The benefits of being a member of BIMSTEC have been discovered in commerce between the bloc's members. Having a shared border between members' countries also has a beneficial association with bilateral trade, demonstrating a significant proof of favourable trade within the bloc even before an FTA was established.

This study suggests that India's export-import (EXIM) strategies, processes, and trade barriers should be simplified, particularly by permitting duty-free imports of capital goods and other inputs used in export products. In addition, massive infrastructure investment and expansion, as well as technology advancement, are required in India for the feasibility and sustainability of trade links between BIMSTEC and other countries around the world.

\section{References}

[1] Aliyu, S. U., \& Bawa, S. (2015). Gravity model by panel data approach: empirical evidence from Nigeria. International Journal of Trade and Global Markets, 8(1), 42-57.

[2] Anderson, J. E. (2016). The gravity model of economic interaction. Boston College and NBER.

[3] Baltagi, B.H., Egger, P., Pfaffermayr, M.(2003), "A Generalized Design for Bilateral Trade Flow Models", Economics Letters, 80, p. 391-7.

[4] Banik, N. (2006). How promising is BIMSTEC?. Economic and Political Weekly, 5264-5268.

[5] Banik, N. (2007). The BIMSTEC FTA and its relevance. Centre for study in International Relations and Development: Discussion Paper\# 36.

[6] Batra, A. (2006). India's Global Trade Potential: The Gravity Model Approach. Global Economic Review, 35(3), 327-361.

[7] Bergstrand, J.H.(1990), "The Heckscher-Ohlin-Samuelson Model, the Linder Hypothesis and the Determinants of Bilateral Intra-Industry Trade", Economic Journal, 100, pp. 1216-29.

[8] Bhargava, A., Franzini, L., Narendranathan, W. (1982), "Serial Correlation and the Fixed Effects Model", Review of Economic Studies, 49, pp. 533-49.

[9] Bhattacharyya, R., \& Banerjee, T. (2006). Does the gravity model explain India's direction of trade? A panel data approach.

[10] Bhattacharya, S. K., \& Bhattacharyay, B. N. (2006). Prospects of regional cooperation in trade, investment and finance in Asia: an empirical analysis on BIMSTEC countries and Japan.

[11] Breuss, F., Egger, P.(1999), "How Reliable Are Estimations of East-West Trade Potentials Based on CrossSection Gravity Analyses?", Empirica, 26, pp. 81 -94.

[12] Deluna Jr, R. (2013). Trade performance and potential of the Philippines: an application of stochastic frontier gravity model.

[13] Dembatapitiya, P., \& Weerahewa, J. (2015). Effects of regional trading agreements on South Asian trade: A gravity model analysis.

[14] Egger, P.(2000), "A Note on the Proper Econometric Specification of the Gravity Equation", Economics Letters, 66, pp. 25-31.

[15] Egger, P.(2002), "An Econometric View on the Estimation of Gravity Models and the Calculation of Trade Potentials", World Economy, 25, pp. 297-312.

[16] Frankel, J., Rose, A.(2002), "An Estimate of the Effect of Common Currencies on Trade and Income", Quarterly Journal of Economics, 117, pp. 437-66.

[17] Helpman, E., Krugman, P.R.(1985), Market Structure and Foreign Trade, MIT Press, Massachusetts.

[18] Helpman, E., Melitz, M., Rubinstein, Y.(2008), "Estimating Trade Flows: Trading Partners and Trading Volumes", Quarterly Journal of Economics, 123, pp. 441-87.

[19] Kabir, M., \& Salim, R. (2010). Can Gravity Model Explain BIMSTEC's Trade? Journal of Economic Integration, 25(1), 143-165. Retrieved April 17, 2020, from www.jstor.org/stable/23000969.

[20] Kabir, M., Salim, R., \& Al-Mawali, N. (2017). The gravity model and trade flows: Recent developments in econometric modeling and empirical evidence. Economic analysis and policy, 56, 60-71. 
[21] Kepaptsoglou, K., Karlaftis, M. G., \& Tsamboulas, D. (2010). The gravity model specification for modeling international trade flows and free trade agreement effects: a 10-year review of empirical studies. The open economics journal, 3(1).

[22] Kaur, G., \& Gupta, A. (2020). India-BIMSTEC Bilateral Trade Activities: A Gravity Model Approach. In Regional Trade and Development Strategies in the Era of Globalization (pp. 126-145). IGI Global.

[23] Kaur, G., \& Sarin, V. Analysis of Trade Diversion and Trade Creation Effect Between India and ThailandA Gravity Model Approach.

[24] Laskar, S. (2015). Determinants of Trade and FDI flows in the BRICS countries-Evidences from Gravity Model Analysis (Doctoral dissertation).

[25] Linder, S.B.(1961), An Essay on Trade and Transformation, John Wiley, New York.

[26] Mishra, A. K., Gadhia, J. N., Kubendran, N., \& Sahoo, M. (2015). Trade flows between India and other BRICS countries: An empirical analysis using gravity model. Global Business Review, 16(1), 107-122.

[27] Narayan, S., \& Nguyen, T. T. (2016). Does the trade gravity model depend on trading partners? Some evidence from Vietnam and her 54 trading partners. International Review of Economics \& Finance, 41, 220-237.

[28] Pesaran, M.H.(2004), "General Diagnostic Tests for Cross Section Dependence in Panels", Cambridge Working Papers in Economics 0435, University of Cambridge, Cambridge.

[29] Rahman, M., Shadat, W. B., \& Das, N. C. (2006). Trade potential in SAFTA: An application of augmented gravity model. CPD occasional paper series, 61, 512.

[30] Rasoulinezhad, E., \& Jabalameli, F. (2018). Do BRICS Countries Have Similar Trade Integration Patterns? Journal of Economic Integration, 33(1), 1011-1045.

[31] Razzaghi, S., Ali, M., Azad, M., \& Sofi, Y. (2012). The Determinants of Trade Flows between D-8 Group Members through Gravity Model. Journal of Basic and Applied Scientific Research, 2(6), 5726-5731.

[32] Saxena, S., \& Bhadauriya, S. (2012). India and Bimstec: An Analysis of India's Trade Performance \& Prospects. Business Analyst: A Refereed Journal of Shri Ram College of Commerce, 33(1), 103-114.

[33] Saxena, S., \& Bhadauriya, S. (2012). India and Bimstec: An Analysis of India's Trade Performance \& Prospects. Business Analyst: A Refereed Journal of Shri Ram College of Commerce, 33(1), 103-114.

[34] Serlenga, L., Shin, Y.(2007), "Gravity Models of Intra-EU Trade: Application of the CCEP-HT Estimation in Heterogeneous Panels with Unobserved Common Time Specific Factors", Journal of Applied Econometrics, 22, 361-81.

[35] Srinivasan, T. N. (2010). Global trading system: decline of nondiscrimination and rise of preferential trade arrangements and agreements. Stan. J. Int'l L., 46, 199.

[36] Tan, X. J., \& Zhou, M. R. (2015). Export potential of 21st-century Maritime Silk Road and its determinants: an empirical research based on stochastic frontier gravity model. Journal of International Trade, 2, 3-12.

[37] Wang, X., \& Badman, R. P. (2016). A multifaceted panel data gravity model analysis of Peru's foreign trade. arXiv preprint arXiv:1612.01155.

[38] World Bank(2008), World Development Indicators 2008, World Bank: Washington, D.C.

[39] WTO(2008), Trade Policy Review: Report by the Secretariat - Thailand, WTO, Geneva. 